\title{
A ESCRITA DO EXÍLIO COMO UM DISCURSO SOBRE O AUSENTE, EM ON CANAAN'S SIDE, DE SEBASTIAN BARRY
}

\author{
Elisa Lima Abrantes ${ }^{1^{*}}$ \\ ${ }^{1}$ Universidade Federal Rural do Rio de Janeiro, Rio de Janeiro, RJ, Brasil
}

\begin{abstract}
Resumo
Neste artigo discuto a questão do exílio no romance On Canaan's Side (2011), tecendo considerações sobre o sujeito diaspórico desenvolvidas por Silviano Santiago (1978), Homi Bhabha (1995) e Edward Said (2003). O romance é uma autobiografia de uma personagem de ficção, cuja história pessoal se entrelaça a episódios traumáticos da história da Irlanda e dos Estados Unidos, país em que a protagonista vive exilada desde a década de 1920. A meu ver, a prática historiográfica nomeada micro-história (Ginzburg; 2006) assemelha-se ao tipo de história que Sebastian Barry escolhe contar, bem como a escrita da história como um discurso sobre o ausente (Certeau; 2011), usada alegoricamente pelo autor no romance. Palavras-chave: Literatura Irlandesa; Sebastian Barry; Exílio
\end{abstract}

\section{WRITING FROM EXILE AS A DISCOURSE OF ABSENCE IN SEBASTIAN BARRY'S ON CANAAN'S SIDE}

\begin{abstract}
In this article, I discuss the issue of exile in the novel On Canaan's Side (2011), weaving considerations about the diasporic subject developed by Silviano Santiago (1978), Homi Bhabha (1995) and Edward Said (2003). The novel is an autobiography of a fictional character, whose personal history is intertwined with traumatic episodes of the history of Ireland and the United States, country in which the protagonist has been in exile since the 1920s. In my view, the historiographic practice named microhistory (GINZBURG; 2006) resembles the kind of history Sebastian Barry chooses to tell, as well as the writing of history as a discourse about the absent (CERTEAU; 2011), used allegorically by the author in the novel. Keywords: Irish Literature; Sebastian Barry, Exile
\end{abstract}

\footnotetext{
" Possui doutorado em Literatura Comparada pela Universidade Federal Fluminense e pós-doutorado em Estudos Irlandeses pela Universidade de São Paulo. Atualmente é vice-presidente da Associação Brasileira de Estudos Irlandeses (ABEI) e faz parte da comissão editorial do ABEI Journal. Desde 2010 é professora e pesquisadora de literaturas de língua inglesa do Departamento de Letras e Comunicação Social do Instituto de Ciências Humanas e Sociais da Universidade Federal Rural do Rio de Janeiro. E-mail: elisa.abrantes2012@ gmail.com. ORCID: 0000.0001-9751-9930.
} 


\section{Introdução}

Sebastian Barry, poeta, dramaturgo e romancista irlandês, nasceu em 1955, em Dublin e graduou-se nas línguas inglesa e latina pela Trinity College Dublin. No final da década de 1970 e início de 1980 viveu fora da Irlanda dando aulas de inglês na França, Suíça, Inglaterra, Grécia e Itália. Em meados de 1980 retornou ao seu país e iniciou sua carreira de escritor. Desde então transita pelos gêneros poesia, romance e drama. Uma característica da obra de Barry é o seu interesse por personagens liminares, "restos da história, homens e mulheres derrotados e rejeitados por sua época [...]. Eles são inadaptados, anômalos, estrangeiros" (O’TOOLE, 1997, p. vii, tradução nossa). Segundo Liam Harte (2014), "sua afinidade particular é pelos indivíduos obscuros da história, que por conta de suas escolhas pessoais, obrigações públicas, ou afiliações políticas, foram excluídos da grande narrativa nacionalista irlandesa" (p. 198, tradução nossa) que excluía os irlandeses que não fossem nacionalistas e católicos.

O romance irlandês On Canaan's Side (2011) constrói uma autobiografia de uma personagem de ficção para refletir sobre a diáspora irlandesa, o exílio e mostrar como eventos históricos traumáticos moldam a subjetividade individual. Integralmente ambientada nos Estados Unidos, a obra reflete sobre a condição do exílio a partir da história pessoal de uma senhora irlandesa de 89 anos, Lilly Bere, que decide acabar com a própria vida após a morte de seu neto único. Segundo Izarra (2018), os escritores de autobiografias [de sujeitos diaspóricos] "tendem a ser, de certo modo, etnograficamente orientados, já que eles dissecam modos e convenções morais, e registram os processos de adaptação, assimilação e integração dos imigrantes" (p. 316, tradução nossa). Consideramos que a escrita de Barry, no romance em questão, apresenta um viés etnográfico ao narrar a experiência de exílio da personagem Lilly. Seguindo os elementos apontados por Izarra (2018) no modelo etnográfico, verificamos que o romance retrata a experiência da emigração, com a travessia do Atlântico e a adaptação a uma nova cultura; a adaptação de Tadg alinhada à ideologia do Sonho Americano, o apego de Lily ao catolicismo como marca do pertencimento irlandês, e a identidade irlandesa-americana de Bill, que tem uma relação de afeto pela Irlanda que não conhece fisicamente.

A narrativa do romance se desenvolve nos dezessete dias que separam o suicídio do neto - que não se recuperou emocionalmente de ter lutado na Guerra do Golfo - do suicídio da avó. Os capítulos são intitulados como os dias passados sem o rapaz: Primeiro dia sem Bill, Segundo dia sem Bill, e assim por diante, até o Décimo-sétimo dia sem Bill. Esses títulos tornam a ausência do neto presente, embora esse personagem seja descrito de forma breve e pouco detalhada no discurso de Lilly. Essa ausência, no entanto, é o que desencadeia a narrativa, posto que há um desejo da parte da narradora de retornar ao passado e relembrar, não só a existência do neto, mas a sua própria história de exilada.

$\mathrm{Na}$ abertura do romance o tom é estabelecido: "Bill se foi. Qual o som de um coração de oitenta e nove anos se partindo? Não deve ser muito mais do que o si- 
lêncio; certamente é um som quase imperceptível" (BARRY, 2011, p. 3, tradução nossa). O leitor se surpreende, engole em seco e antecipa a tristeza que experimentará na leitura. $\mathrm{O}$ que não se percebe de imediato é o poder de reflexão que a obra suscitará durante e após a leitura. O coração de Lilly se parte após muitas dores causadas pelos eventos traumáticos que experimentou.

A personagem compara aquele som à reação que teve aos quatro anos de idade, quando em uma ida à missa em uma igreja em Dublin, com sua linda boneca de porcelana, viu-a cair de seus braços e espatifar-se no chão. Diz que sentiu o coração partir-se da mesma maneira, e que aquela lembrança de quando era uma menina pequena passou a representar para ela o som de seu coração se partindo. Ela se pergunta se "não seria um som como aquele que um coração de oitenta e nove anos emitiria, à parte da dor - um som quase imperceptível" (idem, p. 4, tradução nossa). A lembrança infantil se mantém viva em sua memória e significa a materialização de sua dor.

O romance também nos traz uma reflexão sobre a morte. Para Lilly, a morte do neto é o fim do seu próprio caminho. A personagem procura descrever a dimensão de sua dor:

\begin{abstract}
Mas o sentimento em relação a isso [a morte de Bill] é como uma paisagem submersa por uma inundação, negra, e tudo, lareira e estábulo, animais e humanos, apavorados e ameaçados. É como se alguém, uma grande agência, uma espécie de agência central de inteligência dos céus, soubesse bem o pequeno mecanismo de que sou feita e como [cada parte] é embalada e fixada, e tem o panfleto ou manual para me desfazer; e engrenagem por engrenagem, fio por fio, está fazendo isso, sem intenção de me recompor e indiferente ao fato de que todos os meus pedaços estão espalhados e perdidos. Estou tão aterrorizada pelo pesar que não encontro consolação em coisa alguma. Carrego em meu crânio uma espécie de esfera derretida ao invés de um cérebro, queimando em horror e miséria (idem, p. 4, tradução nossa).
\end{abstract}

Bill era, para ela, o último elo, tanto com a Irlanda, país que o neto admirava e do qual se orgulhava descender, quanto com a América, cujos ideais ele lutara para defender na guerra. A reação da senhora à perda do objeto amado pode ser compreendida à luz do ensaio de Freud, de 1917, "Luto e Melancolia," que investiga a natureza dessas condições psicológicas. Segundo Freud, "o luto, de modo geral, é a reação à perda de um ente querido, à perda de alguma abstração que ocupou o lugar de um ente querido, como o país, a liberdade ou o ideal de alguém" (FREUD, 2006, p. 103). Trata-se de uma tristeza profunda e desinteresse pelo mundo externo, como ilustrado na imagem de devastação construída discursivamente por Lilly, mas não é uma condição patológica, já que se espera que seja superado após certo lapso temporal.

A melancolia, por sua vez, traz consigo "a inibição de toda e qualquer atividade, e uma diminuição dos sentimentos de autoestima a ponto de encontrar expressão em autorrecriminação, culminando numa expectativa delirante de punição" (FREUD, 2006, p. 104). Continua Freud: "no luto é o mundo que se torna 
pobre e vazio; na melancolia é o próprio ego. [...] Esse quadro de delírio de inferioridade é completado por uma superação do instinto que compele todo ser vivo a se apegar à vida" (idem, p. 107). A personagem Lilly parece sofrer de melancolia e perde o instinto de autopreservação, encarando o suicídio como opção viável para não ter de se confrontar com a falta do neto.

A afirmação de Freud, "a análise da melancolia mostra que o ego só pode se matar se puder tratar a si mesmo como um objeto" (idem, p. 111), reforça a tese do estado melancólico de Lilly, pela sugestão de sua autopercepção como um objeto, ao fazer uso de palavras como mecanismo, engrenagens, fios, partes, cérebro como uma esfera derretida, na citação anterior.

A protagonista deixa a cidade natal, Dublin, nos turbulentos anos de 1920, e foge para os Estados Unidos que, como o título sugere, é a Canaã, ou a 'terra prometida' dos irlandeses, a fim de escapar de uma ameaça de morte decretada pela organização paramilitar IRA (Exército Republicano Irlandês), dirigida a seu noivo e também a ela, pela sua ligação com o rapaz. Essa ameaça se explica pelo fato de Tadg, o noivo, ter lutado na Primeira Guerra Mundial como parte do exército britânico, e, portanto, na visão daquela organização, era um traidor dos ideais republicanos. Para agravar a situação do rapaz, ao retornar à Irlanda após o fim da guerra, não conseguiu emprego, o que o fez se alistar na força de combate Black and Tans, da Polícia Real Irlandesa, força policial britânica que lutou contra o IRA na guerra de independência irlandesa (1919-1921). Tadg participou, como membro dos Black and Tans, de uma emboscada que matou alguns rapazes do IRA. Essa ligação de Tadg com o estado britânico e o seu envolvimento na morte de militantes do IRA fez com que ele e Lilly tivessem seus nomes incluídos numa lista dos que seriam mortos pela organização paramilitar.

Lily nunca retornou à Irlanda e, ao escrever sobre o país a partir de sua memória, o faz como um discurso sobre o ausente. Embora os capítulos sejam intitulados a partir da ausência do neto, é a história da Irlanda que está sendo contada; o passado morto da protagonista. A discussão aqui proposta sobre o exílio e a escrita da história irlandesa leva em conta o conceito de micro-história, já que focalizamos uma história individual, que acessa o passado por meio da memória e o processo da escrita como um discurso sobre o ausente, inspirando-nos na perspectiva do historiador Michel de Certeau sobre a escrita da história como "discurso sobre o passado, que tem como estatuto ser o discurso do morto" (2011, p.41). Certeau procede à sua análise da prática historiográfica:

O objeto que nele [discurso] circula não é senão o ausente, enquanto o seu sentido é o de ser uma linguagem entre o narrador e seus leitores, quer dizer, entre presentes. A coisa comunicada opera a comunicação de um grupo consigo mesmo pelo remetimento ao terceiro ausente que é o seu passado. [...] No modo dessas conjugações com o ausente, a história se torna o mito da linguagem. Ela torna manifesta a condição do discurso: uma morte. [...] É a relação de cada discurso com a morte que o torna possível (idem). 


\section{O exílio no romance}

A perspectiva de Certeau é pertinente para uma reflexão sobre a forma e o conteúdo do romance, pois a relação com a ausência e a escrita da história pessoal de Lilly, que também é a história da Irlanda, é uma alegoria do discurso historiográfico concebido como uma escrita sobre mortos. O passado morto também opera no exílio, já que o exílio é um local no qual se tenta reconstruir um lugar perdido, a terra natal. Desde o início, a narradora faz digressões que nos levam a conhecer a sua história, atravessada por traumas, perdas e muita dor em um país estrangeiro, embora ela afirme que qualquer lugar pode ser um lar, quando diz: "Lugar algum é uma terra estranha. Cada um dos lugares é um lar para alguém, e, consequentemente, para todos nós" (BARRY, 2011, p. 58, tradução nossa).

$\mathrm{Na}$ citação anterior, pressupõe-se o desenvolvimento, por parte do exilado, de um sentimento de pertencimento em relação ao seu novo local de moradia. Lilly relata a relação de seu noivo com a cidade em que viviam na América: “Tadg havia começado não apenas a gostar de Chicago. Ele havia começado a usar a palavra 'lar' não mais para referir-se a Cork ou à Irlanda" (idem, p. 72, tradução nossa). Seu comentário mostra a percepção que ela tem sobre a experiência do noivo no exílio, no entanto, quando se trata de falar de si mesma, é a Irlanda que está sempre em foco, bem como a sua inadequação ao novo país: "Eu ansiava por estar em casa, fora desse caos americano, de volta ao caos irlandês que eu compreendia melhor, e onde não estaria tão sozinha" (idem, p.164, tradução nossa). Embora a vida no exílio traga novas experiências ao cotidiano e certo grau de assimilação cultural, não se incorpora totalmente a nova realidade; a saudade permanece.

Nessa reflexão sobre o exílio, Barry apresenta ao leitor outro exilado, um grego de nome Eugenides, dono de uma farmácia frequentada por Lilly, que mantinha produtos gregos em sua loja e ensinava um pouco do idioma à protagonista. Esse personagem sentia muita falta de seu país, ouvia música grega e deu de presente a Bill, neto de Lilly, um exemplar de Homero, possivelmente a Ilíada, traduzido para o inglês, quando o rapaz se alistou no exército estadunidense. Podemos perceber como o Sr. Eugenides procurava manter a tradição de seu povo vivendo fora de seu país. Lilly, ao contrário, trazia consigo apenas a Irlanda nostálgica de sua memória, de sua infância e juventude e, materialmente, apenas um quadro de seu irmão Willie, que havia lutado com Tadg na Primeira Guerra e morreu no conflito; no retrato pendurado na parede de casa, Willie trajava um uniforme de soldado. Bill admirava muito aquele retrato e, segundo a protagonista, a cada dia parecia-se mais, fisicamente, com o tio-avô. Esses foram os laços com as origens irlandesas que Lilly manteve por toda a vida no exílio.

Entre a identidade que deixou para trás e a nova, construída por força das circunstâncias, Lilly sentia-se sem identidade própria, fragmentada. Em diversas passagens do romance ela evidencia essa situação, como, por exemplo, quando se desespera com a morte de Tadg e diz não saber mais quem é, em uma América sem a presença dele. O rapaz é assassinado em um museu em Chicago, num passeio de domingo. A moça, com medo de ser morta também, pega um trem para 
Cleveland, abandonando a cidade. Depois de passar por muitas dificuldades e privações, começa a trabalhar como cozinheira na casa de uma senhora de ascendência irlandesa e, depois da morte desta, continua trabalhando para a filha dela, até se aposentar, quando ganha uma casa para viver, como recompensa pelos vinte anos de trabalho para a família.

Cabe destacar que, na reconfiguração de sua identidade, após a desarticulação inicial causada pela separação, o exilado passa a viver em um entrelugar (SANTIAGO, 1978; BHABHA, 1995), um interstício, um terceiro local de enunciação, sua identidade torna-se híbrida, característica da identidade diaspórica. Ou seja, no caso de Lilly, ela não é mais somente irlandesa e nem mais é esse o seu lugar de fala, nem tampouco é uma americana. Ela habita um espaço intersticial de embate entre as diferenças culturais, transita entre as duas culturas, e é a partir desse espaço discursivo que ela se relaciona com o mundo. Poderíamos dizer, tomando de empréstimo as palavras de Edward Said, que a pátria de Lilly é o que ela escreve, pois no exílio "seu único lar disponível agora, embora frágil e vulnerável, está na escrita" (SAID, 2003, p. 58), já que por meio da escrita, Lilly pode recriar suas raízes, uma realidade longínqua da Irlanda que guarda dentro de si. Said comenta o desconforto característico do entrelugar habitado pelo exilado em sua autobiografia, intitulada sugestivamente Fora de Lugar:

Ainda hoje me sinto longe de casa [...] estas memórias são, em certo plano, a reencenação da experiência da partida e da separação do momento em que sinto a pressão do tempo que se esvai. $\mathrm{O}$ fato de viver em Nova York com a sensação do provisório apesar de 37 anos de residência aqui salienta mais a desorientação do que as vantagens que auferi (SAID, 2004, p. 105).

O entrelugar traz consigo a sensação do provisório, do incerto. Trata-se de uma posição que guarda os vestígios de um mundo interno perdido e de uma vida externa dissonante, regida por outros referenciais, o que implica sempre uma vida fora do lugar. Por ter deixado o seu país, o exilado vê-se a partir de outra perspectiva, do lado de fora, impossível de se alcançar quando se está enredado em seus referenciais espaciais, temporais, sociais e psicológicos moldados desde a primeira infância. A própria forma do romance reforça essa ideia de um entrelugar, já que a narrativa de Lilly transita continuamente pelo presente e o passado, a Irlanda e os Estados Unidos, sem marcar o espaço de uma ou outra categoria.

A visão distanciada de si mesmo e de suas origens será fundada na memória do exilado, sabidamente subjetiva e notadamente influenciada pela sua experiência dolorosa como indivíduo. "Sua tristeza essencial jamais poderá ser superada. As realizações do exílio são permanentemente minadas pela perda de algo deixado para trás para sempre." (SAID, 2003, p. 46). Essa experiência torna-se uma marca do trauma do exílio forçado e reflete-se na solidão, na perda de identidade, na dor, no estranhamento, no sentimento de perda. Tal condição existencial fará o indivíduo experimentar sentimentos de nostalgia e/ou de negação em relação a diversos aspectos de seu país, como mecanismos de defesa para suportar a dor que atravessa. 
Cabe aqui dizer que nem todo exílio é traumático, pois, se as circunstâncias que levam a ele são de escolha do exilado e se pode voltar ao local de origem a qualquer momento, não se trata de experiência traumática. No caso de Lilly, contudo, identificamos o trauma, pois além de ter sido forçada a emigrar, ela não poderia voltar à Irlanda, já que a ameaça de morte persistia. Barry ilustra com Lilly o que o crítico Edward Said postula em seu livro Ensaios sobre o Exílio, quando diz que "o exílio é uma fratura incurável entre um ser humano e um lugar natal, entre o eu e seu verdadeiro lar" (SAID, 2003, p. 46). Mesmo no exílio, a pátria não é arrancada de dentro do indivíduo. Ela se mantém lá, em suas lembranças, recriada, colorida com as tintas da memória. Não o país real, solo e topografia, mas sim uma representação humana construída a partir de um legado histórico, político, mitológico; o retorno ao que é primevo e que faz parte da constituição da identidade do sujeito. Essa dor do exílio e a sensação de uma vida fora do lugar perpassam todo o romance, bem como os traumas e perdas que Lilly enfrenta ao longo de suas muitas décadas de vida.

Barry desvela os sentimentos contraditórios de se viver no exílio a partir da perspectiva da protagonista. Ela sabe estar, pelo menos a princípio, a salvo da ameaça de morte, o que é uma forma de libertação. Mas, significa também que está desarraigada, distante de seu país, de seus familiares e amigos. Ela perde contato com a família e, para ilustrar essa afirmação, comenta que só soube da morte do pai sete anos após o fato, mesmo assim não sabe onde ele está enterrado. Para ela, os Estados Unidos da América é um lugar que, após os primeiros tempos em que vivia dominada pelo medo de ser morta, é seguro. Porém ela não esquece a Irlanda, a 'sua Irlanda' que ela "ama, apesar de tudo, e é tão grata à América, por finalmente oferecer-lhe um refúgio" (BARRY, 2011, p.191, tradução nossa). Sobre a Irlanda ela diz: "meu próprio país que é estranho a mim" (idem, p. 245, tradução nossa), já que após décadas de vida nos Estados Unidos ela passa a nutrir um sentimento de estranheza pela terra natal. Ao deixar o país nos anos de 1920, uma nova Irlanda surgia com a separação do Reino Unido e a independência política no sul do país. Aquele novo país, Lilly não teve a chance de conhecer.

Em relação aos Estados Unidos, Lilly aprecia a vastidão, como se verifica em passagens do texto: "Eu quase ri ao lembrar Dublin com suas casas baixas, com os telhados curvados como chapéus reverenciando a chuva altiva" (idem, p.62, tradução nossa), diz ao chegar em Nova York, ou, tempos depois, em Cleveland, ao visitar o Luna Park com seu amigo e depois marido americano, o policial Joe Kinderman: "O generoso céu americano estende seus braços abertos sobre nós, as fábricas brilhantes e a selvageria das ruas dos homens" (idem, p.116, tradução nossa). Embora admire o local do exílio, ela exprime a importância que atribui às suas origens, mesmo estando há tantos anos afastada delas. "Maud, Annie, Willie e meu pai nunca me deixam. Não houve um dia em que não bebêssemos uma estranha xícara de chá juntos, em alguma sala de visitas peculiar no fundo de minha memória” (idem, p.251, tradução nossa). 


\section{A História e a escrita da História}

Lilly é a filha caçula de Thomas Dunne, superintendente da Polícia Metropolitana de Dublin, posição assumida após 30 anos de serviços prestados e a mais elevada que um católico, como ele, poderia alcançar. A moça havia passado a infância no Castelo de Dublin, e sua família tinha bastante prestígio e excelente posição financeira durante o império. Seu irmão, William Dunne, cuja história Barry desenvolve no romance A Long, Long Way (2005), se alista no exército britânico e luta na Primeira Guerra Mundial. Se pensarmos que após 1916 os movimentos separatistas tomaram corpo na Irlanda e, que após a guerra de independência irlandesa houve uma guerra civil (1922-1923), que culminou com a separação do Reino Unido e consequente criação do Free State (1922), podemos perceber o quanto o mundo feliz da infância de Lilly é modificado em poucos anos. Ser a favor da união e viver no sul, e não nos seis condados da Irlanda do Norte, ainda ligados ao Reino Unido, significava ser marginalizado na própria pátria, e Barry mostra ao leitor as consequências dessa condição na vida dos envolvidos, personificada, nesse caso, por Lilly e sua família.

A protagonista perde seu irmão na guerra, a família é obrigada a deixar o castelo de Dublin e viver na casa de fazenda da família em Wicklow, por conta da mudança de regime, e seu pai, que defendia o país, passa a ser inimigo da nova nação e é forçado a se aposentar. "Meu pai era superintendente de polícia sob o antigo regime. Ele passou a ser o inimigo da nova Irlanda, ou o que seja a Irlanda agora, ainda que eu não saiba bem o que é aquele país" (BARRY, 2011, p. 42, tradução nossa). Além disso, Lilly fica noiva de Tadg Bere, rapaz de Cork, que lutara na guerra junto com Willie, seu irmão, e que ao voltar para a Irlanda também passara a ser visto com maus olhos, sob a nova ótica nacionalista. O envolvimento amoroso dos dois jovens é responsável pela mudança mais radical na vida de Lilly: deixar a Irlanda para nunca mais retornar, fisicamente, a ela.

Tadg, ao retornar ao país no final da guerra, não consegue emprego e é visto com desconfiança pelos nacionalistas. Principalmente após o Levante de Páscoa de 1916, todos aqueles que apoiavam a união com a Inglaterra, até mesmo os soldados irlandeses tão admirados dois anos antes, quando partiram, passaram a ser vistos como verdadeiros inimigos da nação irlandesa. Como outros de sua geração, mais por falta de oportunidades do que por qualquer ideologia, Tadg se associou à força policial britânica Black and Tans, braço da Real Polícia Irlandesa (RIC) composta majoritariamente por veteranos de guerra, contratados em caráter temporário para auxiliar na manutenção da ordem estabelecida pelo império.

Para infelicidade do rapaz, ao participar de uma ação policial em que quatro rapazes membros do IRA são mortos, Tadg tem sua vida ameaçada e não lhe resta opção a não ser fugir da Irlanda. Lilly, por sua ligação com ele também corre sério risco de ser assassinada. O pai da moça, já aposentado, graças ao alto cargo que ocupara, tem conhecidos que lhe permitem acesso privilegiado à informação de que a filha e o noivo corriam perigo de vida e articula a fuga do casal para os Estados Unidos com identidades falsas, como se fossem irmãos, Tim e Grainne 
Cullen, para que construíssem uma nova vida na América, a salvo dos assassinos que os espreitavam.

Em On Canaan's Side, Barry retrata o dia-a-dia difícil dos imigrantes nos Estados Unidos, em postos de trabalho pouco rentáveis e desprovidos de prestígio, como ajudante de pedreiro e empregada doméstica. Além das dificuldades no exílio, Lilly sofrerá muitas perdas, como o assassinato do noivo em um museu em Chicago, o que a levou a deixar a cidade; o abandono pelo marido norte-americano, Joe Kinderman, quando estava grávida, fato ininteligível para ela, que só mais tarde descobre que o receio do marido era o de gerar um filho negro; o desequilíbrio mental irreversível de seu único filho Ed, que sofre de stress póstraumático desde a volta da Guerra do Vietnã e o suicídio de seu neto, também único, Bill, criado por ela desde os dois anos de idade, que logo após ter voltado da Guerra do Golfo, não resiste ao trauma de ter participado de uma carnificina.

Não é por acaso que a história de Lilly Bere é permeada de fatos históricos que mudam o curso de sua existência, tanto na Irlanda, com a Primeira Guerra, a Guerra de Independência e a Guerra Civil, como nos Estados Unidos, com a Guerra do Golfo, a Segunda Guerra e a Guerra do Vietnã. A mudança de regime na Irlanda, a participação americana nos conflitos e o movimento dos direitos civis são elementos que compõem o pano de fundo do romance. Reforçamos aqui a ideia de que Barry, em sua obra, trata a história fazendo uso da ótica dos anônimos, a quem o escritor dá voz: "nossas historinhas sem importância" (BARRY, 2011, p. 119, tradução nossa), diz Lilly. Ou ainda: "Willie Dunne, um nome perdido na história mundial” (idem, p. 32, tradução nossa), referindo-se ao irmão morto na Primeira Guerra, ou mesmo: "seu nome não deve ser mencionado porque é um nome inútil com uma história inútil” (idem, p. 42, tradução nossa), quando fala de seu pai.

Ao abordar os fatos históricos dessa maneira, Barry deslegitima as grandes narrativas históricas, calcadas em uma visão macroscópica dos acontecimentos e dos chamados 'grandes nomes', aquelas pessoas que tiveram influência decisiva em tais fatos. O que se lê na obra de Barry, ao contrário, são histórias pessoais e familiares, historinhas sem importância, como diz a sua protagonista, que revelam muito da complexidade da identidade irlandesa vista internamente ou do exílio, sob a perspectiva de pessoas comuns, que vivenciaram os momentos históricos que são narrados a partir de um ponto de vista totalizante nas versões históricas oficiais. É como se tivéssemos acesso, por meio da ficção, aos bastidores daqueles momentos, imaginando de que forma tais acontecimentos repercutiram nas vidas das pessoas que não estavam envolvidas diretamente nos conflitos, mas foram atingidas irremediavelmente por suas consequências. Podemos aqui chamar atenção para o tipo de história que Barry escolhe narrar em seus livros. Sua ficção se alinha, nesse sentido, ao conceito de micro-história.

O historiador Carlo Ginzburg explica que na micro-história o enfoque é microscópico nas vidas e ideias de pessoas comuns e em fatos cotidianos de um determinado período, a fim de "descrever por meio de uma intriga inventada e nomes imaginários, os costumes e o modo de viver das pessoas daquele tempo" (GINZ- 
BURG, 2006, p.83). Segundo essa concepção historiográfica, "somente nessa escala reduzida podem ser compreendidas, sem reduções deterministas, as relações entre sistemas de crenças, de valores e de representações, por um lado, e pertencimento social, por outro". (CHARTIER apud GINZBURG, 2006, pp 263-264).

Giovanni Levi em seu artigo "Sobre a micro-história" traz alguns esclarecimentos sobre essa prática historiográfica que parecem refletir a intenção de Barry ao tratar da história irlandesa:

[A pesquisa na micro-história] tem sempre se centralizado na busca de uma descrição mais realista do comportamento humano, empregando um modelo de ação e conflito do comportamento do homem no mundo, que reconhece sua - relativa - liberdade além, mas não fora, das limitações dos sistemas formativos prescritivos e opressivos. Assim, toda a ação social é vista como o resultado de uma constante negociação, manipulação, escolhas e decisões do indivíduo, diante de uma realidade normativa que, embora difusa, não obstante oferece possibilidades de interpretações e liberdades pessoais. A questão é como definir as margens, por mais estreitas que possam ser, da liberdade garantida a um indivíduo pelas brechas e contradições dos sistemas normativos que o governam. Em outras palavras, uma investigação da extensão e da natureza da vontade livre dentro da estrutura geral da sociedade humana. Neste tipo de investigação, o historiador não está simplesmente preocupado com a interpretação dos significados, mas antes em definir as ambiguidades do mundo simbólico, a pluralidade das possíveis interpretações desse mundo e a luta que ocorre em torno dos recursos simbólicos e também dos recursos materiais (LEVI, 1992, p. 135).

Acreditamos que a escolha de Barry por uma narrativa que sublinhe as hesitações, escolhas e decisões dos indivíduos e que, principalmente, não esteja comprometida com interpretações dos fatos, mas sim com a exposição da ambiguidade e pluralidade desses, seja acertada para uma melhor compreensão do pertencimento irlandês (Irishness) e o resgate da história pessoal de sua família, que está entretecida na história da Irlanda.

Barry focaliza, principalmente, os irlandeses que experimentam a difícil realidade de viver à margem em seu próprio país, ou mesmo serem obrigados a deixá -lo, como Lilly, já que a representação da Irlanda construída pelo autor apresenta ao público "o relacionamento tenso entre o sujeito e a nação para aqueles marginalizados por seu gênero, posição social, condições financeiras” (HARTE, 2018, p.9) e também a inadequação a posições políticas e religiosas, que não se alinhassem a narrativa oficial irlandesa, levando-se em consideração que o romance se passa no período que se seguiu ao Levante de Páscoa (1916) e às revoltas que culminaram na divisão do país. Aqui nos referimos àqueles que foram vistos, naquele momento, como traidores da pátria, já que não se encaixavam na narrativa oficial de uma Irlanda nacionalista, republicana e católica. A família de Lilly, por exemplo, era católica e não se opunha ao Estado Britânico, ao contrário, seu pai exercia um alto cargo administrativo naquela estrutura, como superintendente da polícia britânica, e seu prestígio e reputação eram consideráveis antes de 1916. 
Expor e buscar sentido na questão do Irishness examinando a marginalização imposta a cidadãos irlandeses, por conta de suas afiliações, parecem ser o foco do poeta, dramaturgo e romancista. Na ótica do autor, ao contrário do que as narrativas históricas irlandesas oficiais do nacionalismo parecem querer fazer crer, as identidades individuais, muitas vezes, estiveram em conflito com a ideologia nacionalista. Não são emitidos juízos de valor, mas a pluralidade das afiliações é exposta na narrativa. A protagonista de On Canaan's Side chama nossa atenção para essa pluralidade ao comentar sobre a parcialidade da história oficial, a dos vencedores, no caso irlandês os nacionalistas, cotejada com a sua própria percepção dos fatos:

Sempre penso com meus botões sobre o que li a respeito do período da guerra da independência, a captura dos rebeldes, sua prisão em algum lugar do castelo [de Dublin], receio que torturados, e me pergunto se esteve meu pai envolvido naquilo? [...] Não sei o quanto aquelas histórias pesam contra os perdedores, no caso homens como o meu pai, leais aos reis e à falecida rainha [Victoria], mas tenho certeza de que houve mal e crueldade de ambos os lados (BARRY, 2011, p. 41, tradução nossa).

A visão de Lilly é bastante ponderada. Ela comenta em outras passagens do livro sobre a admiração e o amor que sente pelo pai, mas diz não querer dar desculpas ou negar os atos cruéis que ele possa ter cometido. No entanto, por reforçar a lealdade do policial ao império, a personagem parece querer chamar a atenção para o fato de que, devido à sua afiliação, ele estava do lado errado da história.

Por conta da intenção de suicídio, a protagonista, que comenta não gostar e nem saber escrever, resolve fazê-lo para deixar um legado, registrar histórias que não devem ser esquecidas. A sua própria história está tão estreitamente ligada à história da Irlanda que o seu testemunho servirá para uma melhor compreensão da opressão sofrida por muitos que estavam no lugar errado e na hora errada, como costumamos dizer no Brasil. Essa ideia nos remete ao comentário de Lilly sobre a sua patroa: "ela era uma americana de ascendência irlandesa que amava a Irlanda e a ideia de sua liberdade, para ela heroica e inspiradora" (idem, p. 42, tradução nossa) e complementa: "como era de fato, tenho certeza, a menos que você estivesse do lado errado" (idem, p. 43, tradução nossa).

A caçula de Thomas Dunne estava 'do lado errado' sem ter escolhido propriamente um lado. Nascera e se criara em uma família que por muitas gerações servira aos interesses do império e, essa lealdade era motivo de orgulho. Com a mudança de regime em seu país, famílias como a dela passaram a personificar a traição aos interesses nacionais, por conta de sua aliança com os opressores. É esse 'outro lado' da história irlandesa, o de uma família irlandesa católica que acreditava e apoiava o império e defendia a 'sua velha Irlanda', que Barry explora no romance ao escrever a autobiografia ficcional de Lilly Bere. A narrativa de Lilly possibilita uma leitura em contraponto (SAID, 2003) à versão oficial da história, evidenciando a sua natureza de construto discursivo, que teve em vista a hegemonia, sobre memórias coletivas diversas, de uma memória histórica adequada à reprodução do poder dominante. 


\section{Considerações finais}

Na narrativa ficcional de Barry, a morte do personagem Bill foi o que motivou o relato da avó, que, segundo ela mesma, não gosta e não sabe escrever. A necessidade de fazê-lo no momento que separa duas mortes - a do neto da sua própria - parece querer manter viva a lembrança de Bill. Lilly traz Bill de volta à vida, a partir do momento em que o transforma em matéria prima da narrativa. E não é dessa mesma maneira que a escrita da história traz o passado à tona? A escrita da história também luta contra o esquecimento. Observemos o que diz Certeau ao comentar sobre a narrativa que se faz dos personagens históricos: "a historiografia tem a estrutura de quadros que se articulam em uma trajetória. Ela representa mortos no decorrer de um itinerário narrativo" (1982, p. 103). Lilly evoca o passado ausente e cria sentidos para a sua própria história e, por extensão, a de seu país. Analogamente, podemos pensar no mecanismo empregado pela história para estabelecer relações e produzir sentidos entre passado e presente, mortos e vivos:

A escrita representa o papel de um rito de sepultamento; ela exorciza a morte introduzindo-a no discurso. Por outro lado, tem uma função simbolizadora; permite a uma sociedade situar-se, dando-lhe, na linguagem, um passado, e abrindo assim um espaço próprio para o presente: "marcar" um passado, é dar um lugar à morte, mas também redistribuir o espaço das possibilidades, determinar negativamente aquilo que está por fazer e, consequentemente, utilizar a narratividade, que enterra os mortos, como um meio de estabelecer um lugar para os vivos. A arrumação dos ausentes é o inverso de uma normatividade que visa o leitor vivo, e que instaura uma relação didática entre o remetente e o destinatário (CERTEAU, 1982, p. 12).

O historiador Marc Bloch também caracterizou a história, enquanto historiografia, como "uma ciência dos homens no tempo, movida pela intenção de unir o estudo dos mortos ao dos vivos" (2001, p. 23). Trazer o passado de volta ao presente, reviver mortos, só é possível através da memória, como a personagem descreve ao comentar sobre o que se passa quando fixa seu olhar nas fotos de seu irmão Willie, seu marido americano Joe Kinderman, seu filho Ed e seu neto Bill, todos em seus uniformes de soldados ou de policial, no caso de Joe. "Não que eu possa vê-los, propriamente, mas eles estão vívidos e iluminados, como sempre estiveram, quando os vejo com olhos da mente" (BARRY, 2011, p. 122, tradução nossa). Ou ainda ao relembrar seu noivo irlandês:

estou cansada, mas por alguns momentos estive apaixonada por Tadg Bere novamente. Que estranho, que estranho. Podemos ficar imunes ao tifo, ao tétano, à catapora, à difteria, mas nunca à memória. Não há vacina contra ela (idem, p. 83).

O relato de Lilly faz parte da sua história pessoal, mas também da história irlandesa. A sua história, como muitas outras contemporâneas a ela, são histórias 
de anônimos, que participaram ou testemunharam determinado momento histórico. Essa perspectiva se alinha à abordagem da micro-história, que faz uma microanálise do passado histórico por meio da observação, em escala reduzida, de elementos culturais, econômicos e sociais daquela época, como, por exemplo, a análise da vida de pessoas comuns. Portanto, não só a morte do personagem Bill engendra um discurso pessoal em busca de sentido para aquela morte [de Bill] e para aquela vida [de Lilly], mas o próprio discurso do que está ausente é um relato, assim como os observados sob a perspectiva da micro-história, que como enfatizamos, se concentra nos pequenos fatos do cotidiano de pessoas que viveram os fatos históricos amplamente conhecidos.

Barry reforça sua escolha pelo método de análise microscópica empregado pela micro-história quando faz Lilly dizer: "gosto de histórias que as pessoas contam de boca, ou gob, como costumávamos dizer na Irlanda. Histórias improvisadas, engraçadas, não as depressivas estórias da história” (BARRY, 2011, p. 9, tradução nossa).

Os acontecimentos registrados na macro-história oficial irlandesa - a grande história das guerras e dos movimentos revolucionários que aparecem nos livros são vistos internamente, pelo lado de dentro, em On Canaan's Side, sob a perspectiva de uma personagem que não aparece, certamente, nos livros de história, mas que viveu e teve sua vida afetada, modificada e até mesmo destruída por aqueles grandes eventos. No romance, as histórias pessoais, as dores, as vidas roubadas, são, sem dúvida, como tantas outras vidas anônimas, parte constitutiva da história oficial, que Barry escrutina e induz à reflexão crítica a respeito das supostas verdades históricas.

Essa postura se alinha a uma preocupação da historiografia, que como a memória, tem a consciência da dívida (RICOEUR; 2007) e da responsabilidade perante aqueles que, quando vivos, estiveram condenados ao silêncio. Os mortos, sobretudo as vítimas do horror, merecem que se procure e se diga a verdade, com base nos documentos e provas encontradas. Para Ricoeur (2007), em sua obra $A$ memória, a história e o esquecimento, a única maneira possível de se questionar uma narrativa histórica, que tende a se fechar em torno de um sentido e de um significado da realidade, é obrigar a fase representativa ou da escrita historiográfica a articular-se com a fase documental e de compreensão/explicação. Qualquer obra histórica é alvo de atestação ou refutação e está sujeita a críticas e revisões constantes. Por essa razão, as versões oficiais estão sempre sendo revistas, e a literatura tem muito a contribuir para essa revisão.

Nesse sentido, Barry, ao dar voz à Lilly em On Canaan's Side, aponta para a necessidade de reflexão a respeito das nuances de significados tanto das narrativas nacionalistas oficiais da Irlanda quanto das afiliações políticas e suas consequências para aqueles que, como a protagonista, se encontram envolvidos irremediavelmente com elas, apenas por estarem do lado errado da história. 


\section{Referências}

\section{Primária:}

BARRY, Sebastian. On Canaan's Side. London: Faber \& Faber, 2011.

\section{Secundárias:}

BHABHA, Homi. The Location of Culture. London: Routledge, 1995.

BLOCH, Marc. Apologia da História ou o Ofício de Historiador. Rio de Janeiro: Jorge Zahar, 2001.

CERTEAU, Michel de. A Escrita da História. Rio de Janeiro: Forense, 2011.

FREUD, Sigmund. Luto e Melancolia. In: Obras Psicológicas de Sigmund Freud. Escritos sobre a psicologia do inconsciente, vol.2. (1915-1920). Rio de Janeiro: Imago Editora, 2006, p. 99-122.

GINZBURG, Carlo. O Fio e os Rastros. São Paulo: Schwarcz Ltda., 2006.

HARTE, Liam. The Politics of Pity: Sebastian Barry's A Long Long Way (2005). In: ___ Reading the Contemporary Irish Novel 1987-2007. Oxford: WileyBlackwell, 2014, p.197-216.

A History of Irish Autobiography. Cambridge University Press, 2018

IZARRA, Laura, ROGERS, James. Life-Writing and Diaspora I. The Autobiographical Writings of the Irish in the USA and Latin America. In: HARTE, Liam. A History of Irish Autobiography. Cambridge University Press, 2018, p.315-330.

LEVI, Giovanni. Sobre a Micro-História. In: BURKE, Peter (org). A Escrita da História: novas perspectivas. São Paulo: Editora da UNESP, 1992, p. 133-162.

RICOEUR, Paul. A Memória, a História, o Esquecimento. Campinas: Editora da Unicamp, 2007.

SAID, Edward. Reflexões sobre o exílio. In. Reflexões sobre o Exilio e outros ensaios. São Paulo: Editora Schwarcz Ltda., 2003, p. 46-60.

. Fora de Lugar (Trad. José Geraldo Couto). São Paulo: Companhia das Letras, 2004.

SANTIAGO, Silviano. Uma Literatura nos Trópicos. São Paulo: Perspectiva, 1978.

O’TOOLE, Fintan. “Introduction". In: BARRY, Sebastian. Plays I. London: Methuen Drama, 1997, p. vii-xiv.

Recebido em: 26/05/2020

Aceito em: 22/07/2020 